UDC $577.25+579.61$

\title{
DNA metabarcoding of microbial communities for healthcare
}

\author{
I. Ye. Zaets ${ }^{1}$, O. V. Podolich ${ }^{1}$, O. N. Reva ${ }^{2}$, N. O. Kozyrovska ${ }^{1}$ \\ ${ }^{1}$ Institute of Molecular Biology and Genetics, NAS of Ukraine, \\ 150, Akademika Zabolotnoho Str., Kyiv, Ukraine, 03680 \\ ${ }^{2}$ Department of Biochemistry, Bioinformatics and Computational Biology Unit, University of Pretoria \\ Lynnwood road, Hillcrest, Pretoria, South Africa, 0002 \\ zkora@ukr.net,podololga@ukr.net,kozyrna@ukr.net
}

\begin{abstract}
High-throughput sequencing allows obtaining DNA barcodes of multiple species of microorganisms from a single environmental sample. Next Generation Sequencing (NGS)-based profiling provides new opportunities to evaluate the human health effect of microbial community members affiliated to probiotics. DNA metabarcoding may serve as a quality control of microbial communities, comprising complex probiotics and other fermented foods. A detailed inventory of complex communities is a pre-requisite of understanding their functionality as whole entities that makes it possible to design more effective bio-products by precise replacement of one community member by others. The present paper illustrates how the NGS-based DNA metabarcoding allows profiling of both wild and hybrid multi-microbial communities with the example of a kombucha probiotic beverage fermented by yeast-bacterial partners.
\end{abstract}

Ke yw or d s: DNA metabarcoding, microbial communities, healthcare, probiotics

\section{Introduction}

\section{High-throughput sequencing allows obtaining DNA barcodes of microbial communities}

DNA barcode is a short DNA sequence, selected in the genome, that can be used to identify different species, analogously to the black stripes of the Universal Product Code used to distinguish commercial products [1]. The traditional barcoding is designed to identify species isolated from individual specimens using Sanger DNA sequencing. For different groups of organisms the specific barcodes were proposed. For example, the Fungal Working Group has identified a ribosomal internal transcribed spacer (ITS) as the best barcode region for fungi $[2,3]$. The gene of $16 \mathrm{~S}$ RNA became a universal barcode for prokaryotic microorganisms [4]. The standardized barcoding is limited in the identification of only those species, which can be cultured in laboratory conditions that made species profiling incomplete. The introduction of next generation sequencing (NGS) advanced significantly the applicability of the barcoding approach by making it faster, cheaper and capable of simultaneous identifying species of different taxonomic groups, including those, which cannot be cultured [5]. The DNA metabarcoding is referred to the automated identification of multiple species from a single bulk sample, containing entire organisms, or from a single environmental sample, containing degraded DNA [6]. Compared to the standard approaches, metabarcoding by pyrosequencing provides taxonomically more comprehensive data and allows faster performing of large-scale biodiversity research and reducing the labor consumption during sample processing as well as the overall cost of analyzing the bulk samples $[7,8]$. The DNA metabarcoding approach has a wide range of applications in forensics, ecology and paleoecolo-

(C) 2016 I. Ye. Zaets et al.; Published by the Institute of Molecular Biology and Genetics, NAS of Ukraine on behalf of Biopolymers and Cell. This is an Open Access article distributed under the terms of the Creative Commons Attribution License (http://creativecommons.org/licenses/by/4.0/), which permits unrestricted reuse, distribution, and reproduction in any medium, provided the original work is properly cited 
gy. In this review, we highlight the use of metabarcoding for a quality control of beverages and fermented products and for designing new probiotic beverages.

\section{Functional beverages and analysis of microbial communities in fermented products}

DNA metabarcoding of microbial communities as an instrument of community analysis is of great importance for resolving many healthcare problems. The U.S. National Institute of Health has initiated the Human Microbiome Project to characterize the human microbiota and actually to design the personal DNA metabarcode of microbial communities (bacterial, archaeal and fungal) of humans. Metabarcoding of the human gut microbiota showed that different people harbor remarkably dissimilar microbiota, which may be affected by external factors such as lifestyle and dietary specificities [9]. Long-term studies in the United States demonstrated a nearly 100 percent reduction in the rate of coronary heart disease, diabetes in women and colon cancer in men in patients accepting "healthy lifestyle" (reviewed in [10]). The conception of healthy lifestyle assumes consuming the fermented beverages as natural probiotics, as a part of the healthy diet, e.g., yogurt, miso, tamari and kombucha. The food industry needs to assess carefully the safety and efficacy of all new species and strains of probiotics before incorporating them into the food products. The nutraceutical fermented products are produced by complex microbial communities characterized by rather unstable species composition. Using the DNA metabarcoded pyrosequencing approach, the profiling of complex yeast-bacterial/archaeal communities in diverse beverage fermentations allows the control of fermentation processes.

Probiotics are viable microorganisms, the health effect of which is independent of the site of action and the route of administration [11]. Living probiotic microorganisms occupy a wide niche because of keeping gut health [12], boosting immune system [13], memory and mental sharpness [14], preventing cancer [15], allergic disorders [16], diabetes and diabetes-induced impairments [17], etc. Prebiotics, in contrast to probiotics, are non-digestible food ingredients like oligosaccharides, which fuel beneficial host-associated microbiota and enhance the positive action of probiotic microbial organisms. Healthpromoting products, containing a combination of prebiotic and probiotic, are termed synbiotics [11]. One-third of cancer cases might be prevented by the nutritious healthy diet, which also maintains healthy weight and physical activity by consuming synbiotics. Further, the significance of tailor-made prebiotics, probiotics and synbiotics in cancer prophylaxis due to the bio-antimutagenic and desmutagenic activities has been reported [15]. Because of the lactose maldigestion problem and allergy to milk proteins, which are widespread in human population, the fermented non-dairy products seem to become more preferable [18]. These products also are cholesterol free and rich in neuroactive amines tyramine and histamine, as well as in antioxidants, which protect consumers from free radicals.

Fermented probiotic products are produced by complex microbial communities and characterized by rather unstable species composition, which strongly depends on the nutritional sources and possible contaminations. Usually, there exists a core consortium of microorganisms, which establish mutualistic relationships and get rid of any contaminating intruders due to a successful competition and the production of antimicrobial metabolites. On the other hand, the accessory members of the brewing communities are more important for the quality of the final product, and the need in a robust control of these communities is widely recognized. Taking into account that the majority of microbial species are uncultivable and cannot be detected by any microbiological methods, the DNA metabarcoding remains the only known tool to examine and control the fermented food microbial communities. This approach is suitable for the analyses of archaeal, bacterial and yeast diversity in natural fermented foods [19-25] and it is of great importance for a new probiotic/synbiotic design.

In this paper, we illustrate how this approach aims at the analysis of hybrid complex microbial commu- 
nities using as example the DNA metabarcoding of a modified kombucha microbial consortium.

\section{The DNA metabarcoding of a modified kombu- cha microbial consortium}

Kombucha beverage is becoming increasingly popular around the world today as a prophylactic probiotic and healing agent [26], and both the kombucha brewed drink and processed pellicles may be promising probiotic/synbiotic formulations [27]. The presence of tea polyphenols, gluconic acid, glucuronic acid, lactic acid, vitamins, minerals in the brewed drink and cellulose pellicle was reported [26]. The prophylactic and healing effects have been proven in a wide range of laboratories [28-32]. For example, kombucha tea can be considered as a potential strong candidate for future application as a functional supplement for the treatment and prevention of diabetes [32]. Kombucha culture is an example of a multi-microbial community with strong mutualistic relationships between its members - bacteria and yeasts. The studies on cultures have revealed that Kombucha Microbial Community (KMC) may include a variety of yeast species and acetobacteria (reviewed in [27]). During the fermentation of sugar in the tea extract the community members produce a big variety of organic molecules, which prevent $\mathrm{KMC}$ from colonization by other microorganisms. Kombucha culture is promising for a creation of consortia with desired probiotic properties. One of such approaches is based on constructing the hybrid ecotypes of KMC enriched by concomitant microorganisms originated from other fermented products, which are compatible with KMC. Any hybrid ecotype of KMC has been analysed by the DNA barcoded pyrosequencing of the whole hybrid kombucha community DNA and compared to the parental kombucha community structure.

In advance, a non-sterile cabbage juice was inoculated by a kombucha culture and incubated for fermentation. The pellicle formed on a top of cabbage brine was transferred from the resulted fermented product to a fresh portion of medium for kombucha culturing (sweet black tea) and sub-cul- tured several times. Total DNA has been extracted from cultural liquid and pellicle. The DNA metabarcoding has been done by using amplification of $16 \mathrm{~S}$ rDNA and ITS regions and further pyrosequencing for identification of bacterial and yeast species, respectively [33]. The resulted metagenomic data, which summarized the most frequent BLASTN hits, are shown in the histogram in Figure.

In summary, the results of pyrosequencing showed that the hybrid kombucha culture is enriched by bacterial and yeast operational taxonomic units, which were not present in the stock KMC [33]. For example, Lactobacillus sp. has been revealed in hybrid $\mathrm{KMC}$ bacteriome, which was not reported before in the stock KMC. However, lactobacilli are typical in other kombucha ecotypes [25, 34] and fermented cabbage products [21] (see Figure). The brewing communities may be important for the quality of the final product, and the ability to introduce new members into $\mathrm{KMC}$ is of practical importance as a possible way to improve the medicinal properties of the kombucha product. For example, Lactobacillus sp. isolated from the hybrid kombucha could be introduced into a newly constructed kombucha communities with the defined core bacterial and fungal species more readily than some other lactobacilli strains selected from culture collections. Yeast DNA barcoding discovered a much higher number of OTUs in both pellicle and cultural liquid in the hybrid kombucha culture as compared to the parental KMC [33]. Many OTUs were not affiliated to any taxonomic unit because of too weak sequence similarity or showed similarity to unknown and uncultured microorganisms. Represented data show that the promising step in manufacturing of safe probiotics and synbiotics is to design synthetic mini-kombucha communities based on concomitant beneficial and harmless microbial species, using DNA barcoded microbial community profiling.

\section{Conclusion and future perspective}

DNA metabarcoding of microbial communities may serve for many purposes, including quality control of beverages and fermented products. Analysis of 


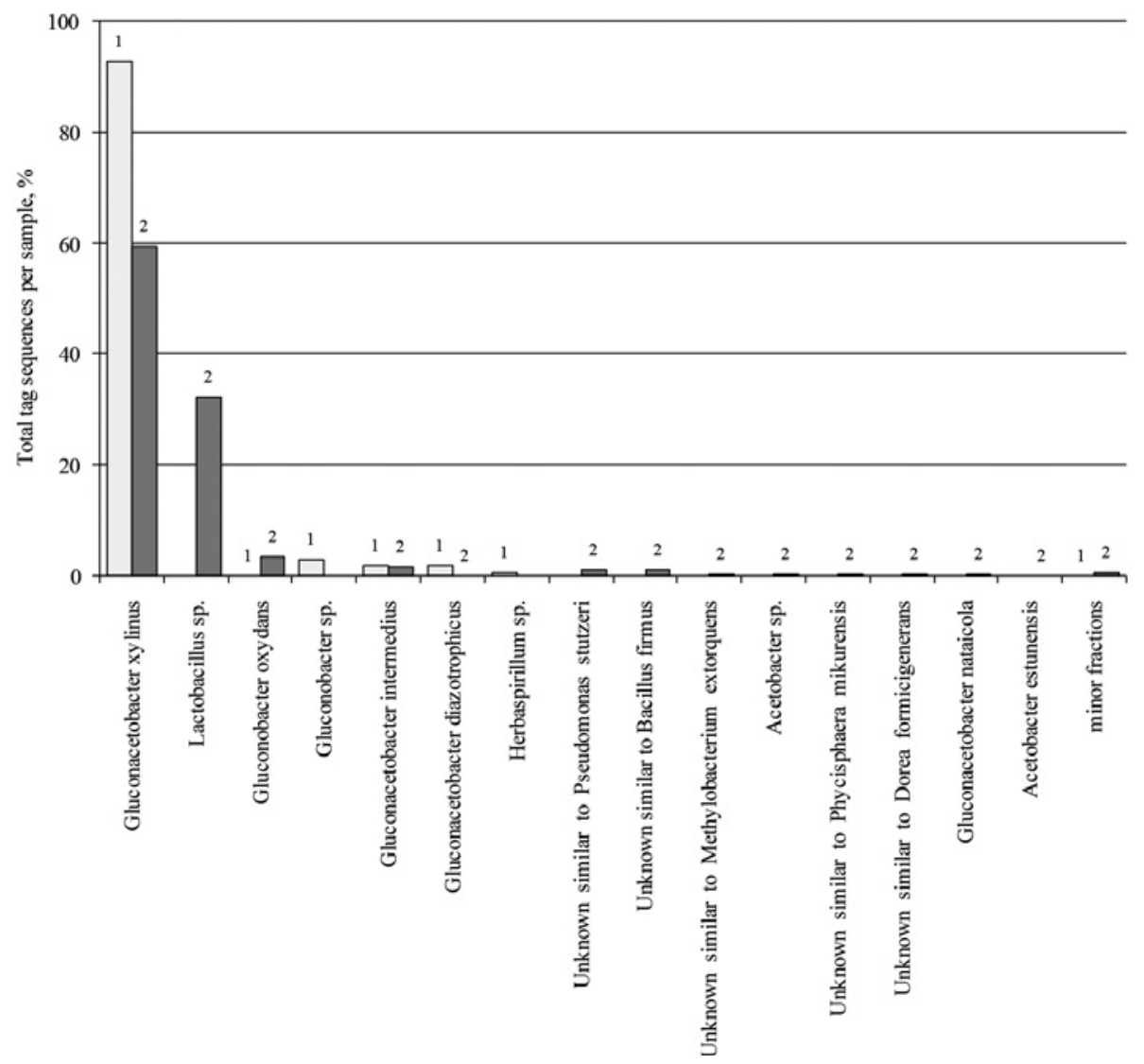

Figure. Relative normalized abundance of the most frequent operational taxonomic units of the hybrid kombucha microbial culture identified by top scored BLASTN hits of $16 \mathrm{~S}$ rDNA reads in the cellulose-based biofilm in comparing with OTUs binned in DNA reads from parental kombucha culture film grown in a sterile black tea with sucrose (sBTS). Numbers of identified reads were normalized by the total numbers of reads in the samples.
DNA metabarcoding data allow mining more complete information about the structure and dynamics of changes in the microbial communities under specific conditions. These data can be used for the prediction of intrinsic relationships in complex microbial communities comprising bacterial, archaeal and fungal taxa and the estimation of the species diversity of natural populations. The DNA metabarcoding displays hidden microbes in microbial communities, which may be of great importance for this community and the probiotic manufacture.

The DNA metabarcoding by pyrosequencing is a new powerful tool for characterizing the dynamic changes in the probiotic communities and in the gut microbiota treated with probiotics. This knowledge may aid in improving the probiotic administration for prophylaxis of human diseases. The profiling of individual human microbiomes may be of great importance for the prognosis of diseases predisposition, su- pervising the course of diseases and development of an individual therapy based on the probiotic administration. The NGS-based species profiling provides new opportunities to evaluate the effect of both individual and community members of probiotics in relation to individual human health. This molecular tool will host local clinics in the future as a routine method aiming at the improvement of health prophylaxis.

\section{REFERENCES}

1. Hebert PD, Ratnasingham $S$, deWaard JR. Barcoding animal life: cytochrome c oxidase subunit 1 divergences among closely related species. Proc Biol Sci. 2003;270 Suppl 1:S96-9.

2. Schoch CL, Seifert KA, Huhndorf S, Robert V, Spouge JL, Levesque $C A$, Chen W; Fungal Barcoding Consortium; Fungal Barcoding Consortium Author List. Nuclear ribosomal internal transcribed spacer (ITS) region as a universal DNA barcode marker for Fungi. Proc Natl Acad Sci USA. 2012;109(16):6241-6. 
DNA metabarcoding of microbial communities for healthcare

3. Blaalid R, Kumar S, Nilsson RH, Abarenkov K, Kirk PM, Kauserud H. ITS1 versus ITS2 as DNA metabarcodes for fungi. Mol Ecol Resour. 2013;13(2):218-24.

4. Woese CR, Fox GE. Phylogenetic structure of the prokaryotic domain: the primary kingdoms. Proc Natl Acad Sci USA. 1977;74(11):5088-90.

5. Margulies M, Egholm M, Altman WE, Attiya S, Bader JS, Bemben LA, Berka J, Braverman MS, Chen YJ, Chen Z, Dewell SB, $D u$ L, Fierro JM, Gomes XV, Godwin BC, He W, Helgesen $S$, Ho CH, Irzyk GP, Jando SC, Alenquer ML, Jarvie TP, Jirage KB, Kim JB, Knight JR, Lanza JR, Leamon JH, Lefkowitz SM, Lei M, Li J, Lohman KL, Lu H, Makhijani VB, McDade KE, McKenna MP, Myers EW, Nickerson E, Nobile JR, Plant R, Puc BP, Ronan MT, Roth GT, Sarkis GJ, Simons JF, Simpson $J W$, Srinivasan M, Tartaro KR, Tomasz A, Vogt KA, Volkmer GA, Wang SH, Wang Y, Weiner MP, Yu P, Begley RF, Rothberg $J M$. Genome sequencing in microfabricated high-density picolitre reactors. Nature. 2005; 437(7057):376-80.

6. Taberlet P, Coissac E, Pompanon F, Brochmann C, Willerslev $E$. Towards next-generation biodiversity assessment using DNA metabarcoding. Mol Ecol. 2012;21(8):2045-50.

7. Ji Y, Ashton L, Pedley SM, Edwards DP, Tang Y, Nakamura A, Kitching R, Dolman PM, Woodcock P, Edwards FA, Larsen TH, Hsu WW, Benedick S, Hamer KC, Wilcove DS, Bruce C, Wang X, Levi T, Lott M, Emerson BC, Yu DW. Reliable, verifiable and efficient monitoring of biodiversity via metabarcoding. Ecol Lett. 2013;16(10):1245-57.

8. Zhou X, Li Y, Liu S, Yang Q, Su X, Zhou L, Tang M, Fu R, Li $J$, Huang $Q$. Ultra-deep sequencing enables high-fidelity recovery of biodiversity for bulk arthropod samples without PCR amplification. Gigascience. 2013;2(1):4.

9. Marzorati M, Maignien L, Verhelst A, Luta G, Sinnott R, Kerckhof FM, Boon N, Van de Wiele T, Possemiers S. Barcoded pyrosequencing analysis of the microbial community in a simulator of the human gastrointestinal tract showed a colon region-specific microbiota modulation for two plantderived polysaccharide blends. Antonie Van Leeuwenhoek. 2013;103(2):409-20.

10. Bengmark $S$. Integrative medicine and human health - the role of pre-, pro- and synbiotics. Clin Transl Med. 2012;1(1):6.

11. Schrezenmeir J, de Vrese M. Probiotics, prebiotics, and synbiotics--approaching a definition. Am J Clin Nutr. 2001;73(2 Suppl):361S-364S.

12. Bernardo WM, Aires FT, Carneiro RM, Sá FP, Rullo VE, Burns DA. Effectiveness of probiotics in the prophylaxis of necrotizing enterocolitis in preterm neonates: a systematic review and meta-analysis. J Pediatr (Rio J). 2013;89(1):18-24.

13. van Baarlen $P$, Wells JM, Kleerebezem M. Regulation of intestinal homeostasis and immunity with probiotic lactobacilli. Trends Immunol. 2013;34(5):208-15.

14. Bested AC, Logan AC, Selhub EM. Intestinal microbiota, probiotics and mental health: from Metchnikoff to modern advances: Part I - autointoxication revisited. Gut Pathog. 2013;5(1):5.
15. Raman M, Ambalam P, Kondepudi KK, Pithva S, Kothari C, Patel AT, Purama RK, Dave JM, Vyas BR. Potential of probiotics, prebiotics and synbiotics for management of colorectal cancer. Gut Microbes. 2013;4(3):181-92.

16. Isolauri E, Salminen S; Nutrition, Allergy, Mucosal Immunology, and Intestinal Microbiota (NAMI) Research Group Report. Probiotics: use in allergic disorders: a Nutrition, Allergy, Mucosal Immunology, and Intestinal Microbiota (NAMI) Research Group Report. J Clin Gastroenterol. 2008;42 Suppl 2:S91-6.

17. Davari S, Talaei SA, Alaei H, Salami M. Probiotics treatment improves diabetes-induced impairment of synaptic activity and cognitive function: behavioral and electrophysiological proofs for microbiome-gut-brain axis. Neuroscience. 2013;240:287-96.

18. Gawkowski D, Chikindas ML. Non-dairy probiotic beverages: the next step into human health. Benef Microbes. 2013;4(2):127-42.

19. Roh SW, Kim KH, Nam YD, Chang HW, Park EJ, Bae JW. Investigation of archaeal and bacterial diversity in fermented seafood using barcoded pyrosequencing. ISME J. 2010;4(1):1-16.

20. Oguntoyinbo FA, Narbad A. Molecular characterization of lactic acid bacteria and in situ amylase expression during traditional fermentation of cereal foods. Food Microbiol. 2012;31(2):254-62.

21. Park EJ, Chun J, Cha CJ, Park WS, Jeon CO, Bae JW. Bacterial community analysis during fermentation of ten representative kinds of kimchi with barcoded pyrosequencing. Food Microbiol. 2012;30(1):197-204.

22. Kim YS, Kim MC, Kwon SW, Kim SJ, ParkIC, Ka JO, Weon HY. Analyses of bacterial communities in meju, a Korean traditional fermented soybean bricks, by cultivation-based and pyrosequencing methods. J Microbiol. 2011;49(3):340-8.

23. Nam YD, Lee SY, Lim SI. Microbial community analysis of Korean soybean pastes by next-generation sequencing. Int $J$ Food Microbiol. 2012;155(1-2):36-42.

24. Nam YD, Park SL, Lim SI. Microbial composition of the Korean traditional food "kochujang" analyzed by a massive sequencing technique. J Food Sci. 2012;77(4):M250-6.

25. Marsh AJ, O'Sullivan $O$, Hill C, Ross RP, Cotter PD. Sequence-based analysis of the bacterial and fungal compositions of multiple kombucha (tea fungus) samples. Food Microbiol. 2014;38:171-8.

26. Vinna I, Semjonovs P, Linde R, Patetko A. Glucuronic acid containing fermented functional beverages, produced by natural yeasts and bacteria associations. IJRRAS. 2013; 14(1):17-25.

27. Kozyrovska NO, Reva OM, Goginyan VB, de Vera J-P. Kombucha microbiome as a probiotic: a view from the perspective of post-genomics and synthetic ecology. Biopolym Cell. 2012; 28(2):103-13.

28. Yapar K, Cavusoglu K, Oruc E, Yalcin E. Protective effect of kombucha mushroom (KM) tea on phenol-induced cytotoxicity in albino mice. J Environ Biol. 2010;31(5):615-21. 
29. Bhattacharya S, Manna P, Gachhui R, Sil PC. Protective effect of kombucha tea against tertiary butyl hydroperoxide induced cytotoxicity and cell death in murine hepatocytes. Indian J Exp Biol. 2011;49(7):511-24.

30. Bhattacharya S, Gachhui R, Sil PC. Hepatoprotective properties of kombucha tea against TBHP-induced oxidative stress via suppression of mitochondria dependent apoptosis. Pathophysiology. 2011;18(3):221-34.

31. Bhattacharya S, Gachhui R, Sil PC. Effect of Kombucha, a fermented black tea in attenuating oxidative stress mediated tissue damage in alloxan induced diabetic rats. Food Chem Toxicol. 2013;60:328-40.

32. Aloulou A, Hamden K, Elloumi D, Ali MB, Hargafi K, Jaouadi B, Ayadi F, Elfeki A, Ammar E. Hypoglycemic and antilipidemic properties of kombucha tea in alloxan-induced diabetic rats. BMC Complement Altern Med. 2012;12:63.

33. Reva ON, Zaets IE, Ovcharenko LP, Kukharenko OE, Shpylova SP, Podolich OV, de Vera JP, Kozyrovska NO. Metabarcoding of the kombucha microbial community grown in different microenvironments. AMB Express. 2015;5(1):124.

34. Chakravorty S, Bhattacharya S, Chatzinotas A, Chakraborty $W$, Bhattacharya D, Gachhui R. Kombucha tea fermentation: Microbial and biochemical dynamics. Int J Food Microbiol. 2016;220:63-72.

\section{ДНК-метабаркодинг мікробних угрупувань для підтримки здоров'я}

\section{I. Є. Заєць, О. В. Подоліч, О. М. Рева, Н. О. Козировська}

Високопродуктивне секвенування дозволяє отримати штрихкоди ДНК декількох видів мікроорганізмів з однієї проби навколишнього середовища. Профілювання видів на основі технологій секвенування нового покоління (СНП) дає нові можливості для оцінки впливу членів мікробних угрупувань пробіотиків на здоров'я людини. Метабаркодинг ДНК може слугувати для контролю якості мікробних угрупувань, включаючи складні пробіотики та інші ферментовані продукти. Детальна інвентаризація складних угрупувань є передумовою розуміння ïx функціональності як цілісного утворення, що дасть можливість створювати більш ефективні біо-продукти шляхом точної заміни одного з членів угрупування/спільноти іншими. Ця стаття показує, як можна застосувати метабаркодинг ДНК на основі СНП для профілювання диких і гібридних мульти-мікробних угрупувань на прикладі пробіотичного напою комбучі, ферментованого дріжджово-бактеріальними партнерами.

Кл юч о в і с с о в а: метабаркодинг ДНК, мікробні угрупування, охорона здоров'я, пробіотики

\section{ДНК-метабаркодинг микробных сообществ для поддержания здоровья}

И. Е. Заец, О. В. Подолич, О. Н. Рева, Н. А. Козыровская

Высокопродуктивное секвенирование позволяет получить штрих-коды ДНК нескольких видов микроорганизмов из одной пробы окружающей среды. Профилирование видов на основе технологий секвенирования нового поколения (СНП) дает новые возможности для оценки влияния микробных членов сообществ пробиотиков на здоровье человека. Метабаркодинг ДНК может служить для контроля качества микробных сообществ, включая сложные пробиотики и другие ферментированные продукты. Детальная инвентаризация сложных сообществ является предпосылкой понимания их функциональности как целостного образования, давая возмлжность создавать более эффективные био-продукты с помощью точной замены одного из членов сообщества другими. Эта статья показывает, как можно использовать метабаркодинг ДНК на основе СНП для профилирования диких и гибридных мульти-микробных сообществ на примере пробиотического напитка комбучи, ферментированного дрожжево-бактериальными партнерами.

К л ю ч е в ы е с л о в а: метабаркодинг ДНК, микробные сообщества, охрана здоровья, пробиотики

Received 10.01.2015 